\author{
1982 年に発生したイバラキ病 \\ 打越律男*1) 江永直樹*1) 下平秀丸*1) 青木保子*1) 南川藤夫*1) 德永光伸*1) \\ 今村重春*1) 原 利視*1) 宮地万吉*1) 梶原忠彰 $* 2$ ) \\ (昭和 58 年 6 月 17 日受理)
}

\begin{abstract}
An Outbreak of Ibaraki Disease in Kyushu, Japan in 1982
Norio Uchikoshi (Chubu Livestock Hygiene Service Center, Prefecture of

Saga, Takagise, Saga 840-01) et al.
\end{abstract}

\title{
SUMMARY
}

In October and November, 1982, three cows were affected with a disease with dysphagia as a main symptom in Saga Prefecture in the Kyushu region. They also suffered from salivation, vomiting, and mild pyrexia and died in 7 to 10 days. Autopsy revealed ulceration on the ventral surface of the tongue, scattered white spots on the mucosal surface of the esophagus, and hyperemia and ulceration on the mucosa of the abomasum. Histological changes noticed were coagulation necrosis of muscle fibers in the tongue, esophagus, and heart and necrosis and ulceration on the ventral mucosal surface of the tongue, Virus isolation was negative when it was tried in blood samples collected from one of the affected cows and one of six cows housed in the same barn as the affected ones, but in vain. Neutralizing antibody against Ibaraki virus was detected from all the affected cows and five of the 6 exposed ones. As a result, the disease was diagnosed as Ibaraki disease, the last outbreak of which was in 1960 in Japan.

要約

1982 年 10 月から 11 月にかけて, 佐賀県下の 3 頭の牛に曣下障害を主徵とする疾病が発生し, 7 日から 10 日の経過ですべて死亡した. 主要な臨床症状は, 軽度の発熱, 流涎, 嚥下障害特よび

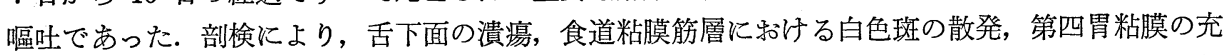
血特よび潰瘍形成が認められ，組織学的検査により，食道特よび舌の筋線維の凝固壊死，舌下面粘 膜の壊死と潰瘍形成, 心筋線維の凝固壊死が認められた. ウイルス分離を発病牛と同居牛のそれぞ れ1頭の血液について試みたが，すべて陰性であった。イバラキウイルスに対する中和抗体は，発 病牛すべてにまた同居牛 6 頭中 5 頭に検出された.

これらの成績から，今回発生した牛の疾病は，イバラキ病であると考学られる。日本に和ける本 病の発生が 1960 年以来 22 年ぶりに認められた.

家畜法定伝染病の一つに，流行性感冒がある.この病 名は. 1949 ・1950 両年に発生したインフルエンザ様疾病 につけられたるのであるが9, その後, 病原的にインフ ルエンザとは無関係であることが明らかになり，牛流行 熱と呼ばれた。 この病気の経過中に咽喉頭麻瘏を示する のがあり, 当時は牛流行熱の後遺症と考兄られ, 異型流 行性感冒ともいわれていた. 1959年, 咽喉頭麻痺を示す

*1) 佐賀県中部家畜保健衛生所（佐賀市高木瀬町高木）

*2) 佐賀県西部家畜保健衛生所（佐賀県武雄市武雄町 富岡）
病牛から新たにウイルスが分離され，ブルータング様ウ イルスまたは家衛試ウイルスといわれ，その病名もブル 一タング様疾病と呼称されるようになった. その後, こ のウイルスはイバラキウイルスと名付けられ, 病名もイ バラキ病として統一された2).

佐賀県下で 1982 年 10 月から 11 月にかけて，22 年ぶ りにイバラキ病と考兄らる疾病の発生があったので, その発生状況扣よび臨床症状を調べるとともに, 病理学 的拉よびウイルス学的検查を行ったのでその成績の概要 を報告する。 


\section{1. 材料および方法}

\section{1) 検 查牛}

1982 年 10 月 20 日へい死した 1 頭の和牛, 11 月 18 日 および 11 月 25 日へい死した 2 頭の乳用牛と同居牛 6 頭 である。

\section{2) 検 查材 料と方 法}

(1) 血液学的検査: 赤血球数 (RBC), 白血球数 (WB $\mathrm{C})$, ヘマトクリット值 $(\mathrm{Ht})$, 白血球百分比について検 查した。

な特，RBC，WBC 数は自動血球計算器により計算し た。

（2）ウイルス学的検查：検查は家畜衛生試験場九州支 場第 3 研究室に依頼して実施した。

ウイルス分離試験は, 脱線維素血液を1日答の乳の及 マウス脳内に $0.01 \mathrm{~m} l$, 牛腎細胞培養に $0.1 \mathrm{~m} l$ づつ接 種し，それぞれ7日和よび 18 日間隔で 2 代継代により 行った.

中和試験はイバラキウイルス No. 2 株の牛謷細胞培着 18代継代ウイルスを用い，血清希釈法により牛腎細胞培 養で実施した。

(3) 細菌学的検查：主要臓器を可検材料とした，好気

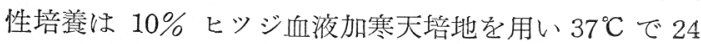
〜 48 時間，嫌気性培盖は 10\% ヒツジ血液加寒天培地和 よび GAM 寒天培地を用い, 炭酸ガス置換法により $37^{\circ} \mathrm{C}$ で 24〜72 時間分離培養を行った.

(4) 病理学的検查 : 主要臓器和よびリンパ節を採取 し, 10\%ホルマリン液で固定し，パラフィン包埋後薄切 し，ヘマトキシリン・エオジン染色を行い鏡検した。

\section{2. 成績}

\section{1) 発生状況と経過}

1982 年 10 月 20 日のへい死和牛 (1 号牛) は, 9 月 29 日 2 産目を分娩した. 10 月 10 日頃から食欲不振とな り，開業獣医師の診療を受け，栄養剂，ビタミン剂等に よる治療を行ったが回復せず，10月18日家畜保健衛生 所に連絡があった. 病状が進行し 10 月 20 日へい死し た. 当該農家は和牛 4 頭を飼育していた（表 1 ）.

11 月 18 日のへい死乳用牛 (2 号牛) は 11 月 3 日分

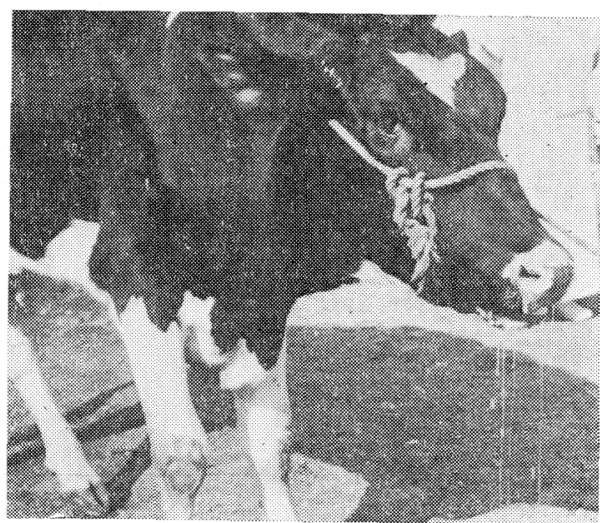

写真 1 飲水の逆出 (2号牛)

娩した. 11月9日頃から食欲不振となり，治療効果もな く11月 18 日へい死した (写真 1 )。当該農家は乳用牛 26 頭を飼養していた（表 1 ）.

11 月 25 日のいい死乳用牛（3号牛）は，11月9 日初 産分娩，11月 14 日から食欲不振がみ吕れ治療したが効 果もなく 11 月 25 日へい死した。当該農家は乳用牛 63 頭を飼養していた（表1）.

3 農家はそれぞれ 20〜30 km 離れて特り，交流はなか った。をた，その後症状学現わした牛はいないが，11 月 18 日に 3 号牛の同居牛全頭について検温したところ， $39^{\circ} \mathrm{C}$ 前後を示すものが数頭みられ感染が疑われた。

\section{2) 臨床症状}

1 号牛では胃が著しく硬く触知され, 食欲不振, 四肢 冷感, 流延著明, 嘔吐, 曣下障害, 舌下面粘膜に潰瘍形 成, 眼球やや陷没, 皮膚硬く脱水症状がみられた.

2 号牛では食欲不振, 流延, 眼球陥没著明, 呼吸音異 常, 後駆蹌踉, 脱水症状, 黑褐色軟便, 嘔吐, 嚥下障害 等がみられた。

3 号牛では食欲不振, 流涎, 嘔吐, 嬹下障害, 舌下面 粘膜に潰瘍形成がみられた。

また， 3 頭の立ら入り検査時の体温は $39.2 \sim 39.5^{\circ} \mathrm{C}$ で あった。

\section{3) 血液学 的所見}

立ち入り検査時の血液所見は，赤血球数は 1 号牛 856 万， 2 号牛が 785 万， 3 号牛が 914 万之正常值を示乙

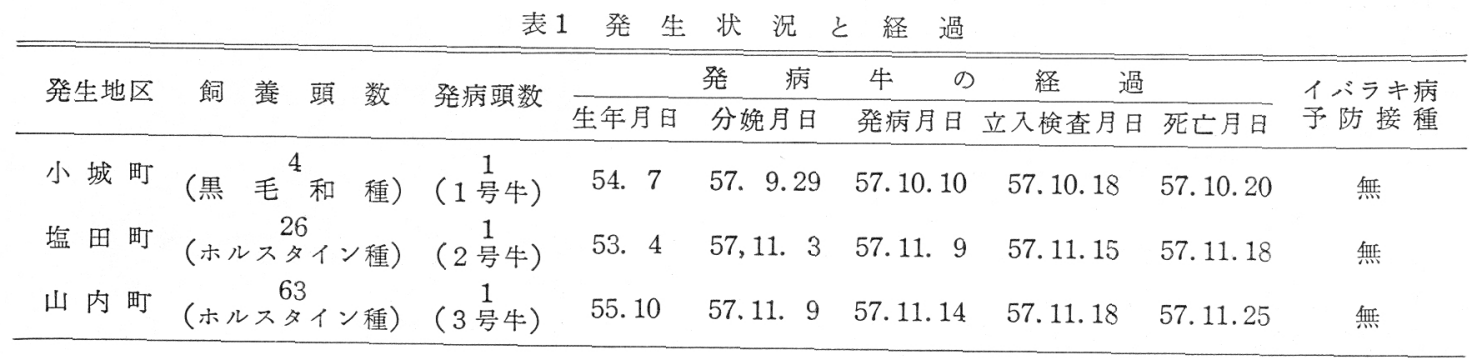


1982 年 $儿$ 発生 表 2 血液学的所見（立入検査時）

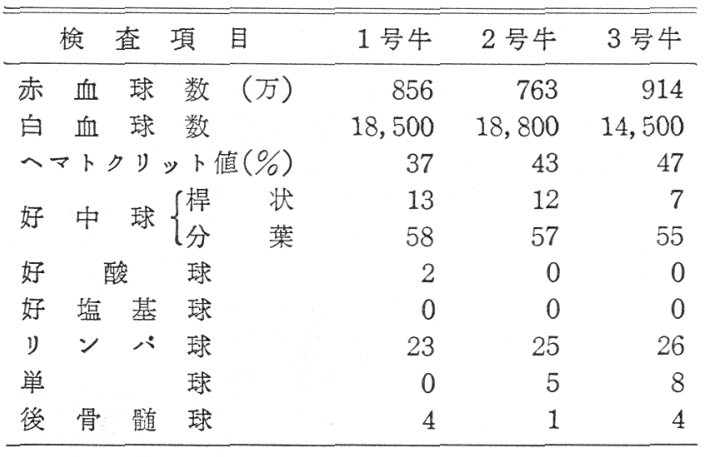

表 3 イバラキウイルスに対する中和試験

\begin{tabular}{ccccc}
\hline \hline 牛番号 & 血清の由来 & $\begin{array}{c}\text { 採血 } \\
\text { 年月日 }\end{array}$ & $\begin{array}{c}\text { 中和 } \\
\text { 抗体価 }\end{array}$ & 備 \\
\hline 1 & 小城町発病牛 & 57.10 .18 & 32 & \\
2 & 塩田町 " & 57.11 .13 & 32 & \\
3 & 山内町 " & 57.11 .19 & 32 & \\
4 & 塩田町 " & 57.11 .18 & 64 & No.2 の後血清 \\
5 & 小城町同居牛 & 57.10 .18 & $<2$ & No.1 の子 \\
6 & 山内町 " & 57.11 .19 & 8 & \\
7 & " & " & 32 & \\
8 & " & & 64 & \\
9 & " & & 8 & \\
10 & " & & 32 & \\
\hline
\end{tabular}

た。白血球数はそれぞれ $18,500 ， 19,100 ， 14,500$ であ った。ヘマトクリット值はそれ先れ $37,40,47$ と高め であった。

白血球百分比は 3 頭とも好中球が約 $70 \%$, リンパ球約 25\%, その他約 $5 \%$ で好中球が増加し，リンパ球が減少 していた（表2）.

\section{4) ウイルス分離と抗体検査}

ウイルス分離には山内町の発症牛 (3 号牛) と同居牛 (6 号牛)の立入検査時に採取した脱線維素血液を用いた が、ウイルスは分離されなかった。

イバラキウイルスに対する中和抗体洒は発应した 1 ・ 2 および 3 号牛ではいずれも 32 倍であったが， 2 号牛 の5 日後の血清では 64 倍であった. また 1 号牛と同居 している1頭では（5号牛），抗体は陰性であったが， 3 号牛と同居している 5 頭（6～10 号牛）では 8～64 倍の 抗体価が認められ, 不顕性感染があったことが示唆され た（表 3 ).

5）細 菌 検 査

へい死した 3 頭の肝臓, 脾臓, 腎葴, 肺, 咽頭, ならびに 顎下リンパ節, 腸内容を好気岕よび嫌気性培盖を行った。 その結果, 腸内容预よび肺から大腸菌が分離された。

6) 病理学的所見

死亡牛の 3 頭について病理学的検査を行い, 下記の成
績が兄られた。

（1）肉眼的所見：1号牛は舌下面に潰瘍, 上口蓋に糜 爛（大豆大） 4 個がみられた。肺は軽度の気腫，うっ血， 硬結巣散在，食道粘膜は平滑で限局性の白色斑が認めら れた。 また第一特よび第四胃粘膜は充血していた。

2 号牛は外鼻孔部の粘膜に化膿性潰瘍形成, 肝臓の腫 大特よび胆管肥厚，脾臓の割面暗赤色，肺は全葉にわた る間質性気腫, 前葉の一部に瞕赤色硬化巣, 第四胃粘膜 は全域にわたる充血掠よび線状ないし点状潰㾤を示し た。

3 号牛は肝臓の軽度の睡大, 肺は吸気状態で膨大, 第 一胃は噴門近位粘膜に偽膜形成, 舌の潰瘍 (写真 2 ), 第 四胃粘膜は充血, 幽門部に点状应るい線状の潰瘍が散 在していた。

\section{(2) 組織学的所見}

『1号牛』: (1)食道筀層の注ぼ全域にわたる等線維の凝 固壊死特よび再生, リンパ球・好中球の軽度の浸瀾, 血 管変性, 充・出血等の巣状病変の多発. (2)舌根部筋層の 等線維の㠜固壊死晾上び再生が多発ないし散発. (3)肺に 括计る䛊與性の気管支肺炎。(4)咽背および顎下リンパ節 に和ける洞カタール。 (5)舌下面粘膜に和ける壊死, 細菌 繁殖, 好中球集簇, 充・出血, 浮腫をともなら深い潰瘍 の形成ならびに硬口蓋粘膜に和ける糜爛形成. (6)心筋線 維の散在性巣状 (凝固) 壊死 (写真 3 ). (7)脾に打ける沪 胞周囲性に好中球浸潤.

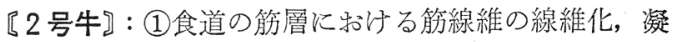

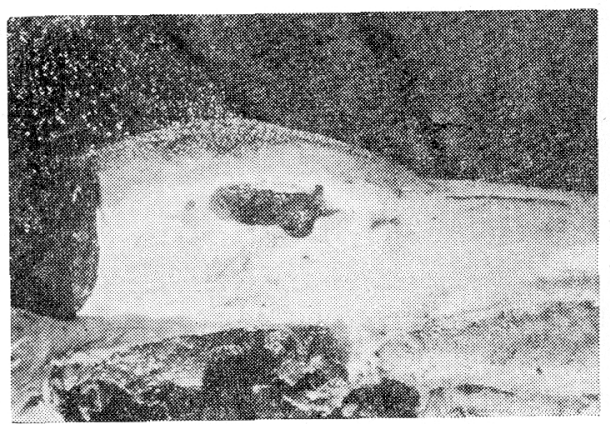

写真 2 舌の潰瘍 (3号牛)

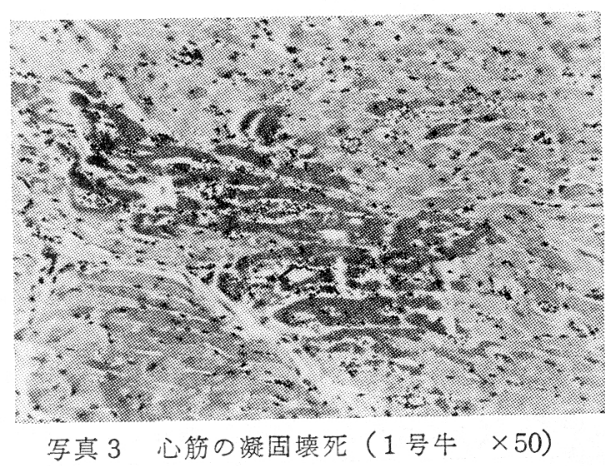




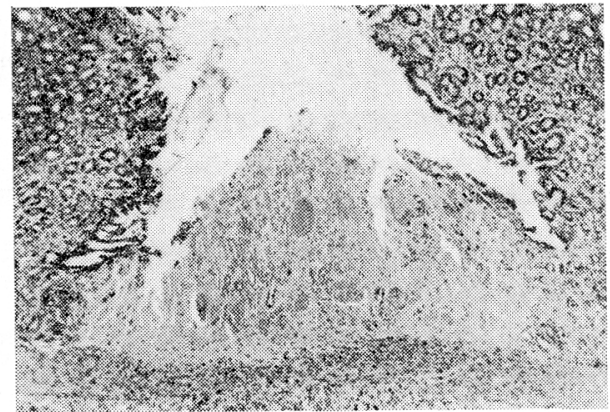

写真 4 第四胃粘膜の壊死 $(2$ 号牛 $\times 20)$

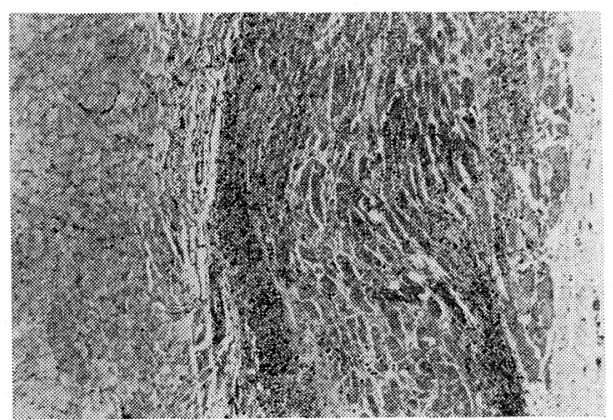

写真 5 食道筋層の線維化をともなら㠜固壊死 ( 3 号牛 $\times 20)$

固壊死巣特よび再生像. (2)舌根部筋線維の軽度の散在性 硝子杽化. (3)外鼻孔粘膜に和ける細菌塊和よび化膿をと もなう深い潰瘍の形成. (4)第四胃粘膜に和けるやや高度 な充血括よび巣状壊死と糜爛の散在(写真4). (5)肺に尔 ける著しい間質性気腫永よび間質結合織の著しい増生. (6)肝に和ける間質結合織の増生ならびに肝細胞の脂肪恋

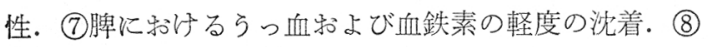
頭頸部のリンー、に和ける RES の活性化和よび洞力タ 一ル。

『3 号牛』: (1)食道筋層に和ける広範な凝固壊死和よび 線維化ないし竻線維の再生の多発(写真 5 ). (2)舌抢よび 咽頭部の筋肉に打汓る㠜固壞死㧍よび線維化巣の散在. (3)舌体部に括ける限局性の深い潰瘍の形成. (4)第一・四 胃粘膜の充・出血, 浮腫, 血栓形成および好中球浸潤を ともなら壞死巣の形成. (5)肺に抢ける著しい細菌繁殖を ともなら壞死巣の散在ならびに誤嚥性化膿性気管支肺 炎. (6)肝細胞の混濁腫脹扎よび空胞変性. (7)脾に和ける 高度ならっ血.

\section{3. 考察}

1982 年 10 月から 11 月の間に, 佐賀県下の 3 頭の牛 に流行性感冒様疾病が発生した. 発病牛の主要症状は, $39^{\circ} \mathrm{C}$ 前後の軽熱, 食欲不振または廃絶, 嘔吐, 流涎, 與 下障害であり, 他に眼球陥没, 舌下面の潰瘍などが認め
徳永光伸 今村重春 原 利視 宮地万吉 梶原忠彰

られた。ささらに剖検では第四胃粘膜の充血と潰瘍形成, 肺気腫を認め, 組織学的検查では食道, 舌および心の筋 線維の凝固䏅死, 第四胃粘膜の充・出血, 潰瘍, 浮腫, 脾臓のらっ血が認められた。

これらの所見は，これまで報告されているイバラキ病 のそれとよく一致した ${ }^{1 \sim 9)}$. ウイルス分離は陰性に終わっ たが，予防液未注射にもかかわらず発病牛はすべてが， また同居牛のほとんどがイバラキウイルスに対する中和 抗体を保有して特り，高率に不顕性感染が認められた。

これらの成績から今回発生した疾病はイバラキ病と診 断された。

家畜法定伝染病の一つである流行性感冒は，行政的に は一過性の高熱, 呼吸速迫などを主徵とする牛流行熱と, 軽熱, 興下障害を主な症状とするイバラキ病のそれぞれ 原因が異なる 2 つ疾病を包含している.イバラキ病は, 1959年に病原ウイルスが分離され，その頃はブルータン グ様疾患として扱われていたが，1969年に大森らにより イバラキ病として統一されている11. 過去に晾子る流行 性感冒の発生状況をみると, 1951，1952 両年には，牛流 行熱とイバラキ病の混合感染が, 1953, 1955, 1956, 1958, 1966 年には牛流行熱，また 1959，1960 両年にはイバラ キ病がそれぞれ単独に流行したとされている. その後, 日本ではイバラキ病の発生はまったく認められていな かった. 今回 22 年ぶりに等発生が確認されたことは, 自然界でのウイルスの存続と伝播に関連して, 疫学上は なはだ與味がもたれるところである.このたびのイバラ キ病の発生は, 疫学的にイバラキ病の流行期である 10 月 から11月にかけて散発的に発生したこと. 臨床的にイ バラキ病の特徵である嚥下障害, 脱水症状, イバラキ病 ワクチン未注射にもかかわらず抗体を保有していたこ と, 解剖的に食道筋層の㠜固壊死, 第四胃粘膜の充血叔 よび潰瘍等からみて牛流行熱との混合感染はなく, イバ ラキ病単独発生であったと考党られる。

また，今回の発病牛についてみると，いずれも分娩後 5〜11日で発病の琵候がみられている。このことは分婏 が発病要因の一つとなりらることを示唆するので，この 点については今後さらに検討したいと考える.

稿を終わるにあたり，ウイルス学的検査ならびに種々 のご指導をしていただいた農林水産省家蓄衛生試験場九 州支場第三研究室の黒木 洋室長に深甚なる謝意を表し ます。

\section{引用文献}

1) 大森常良：牛病学，255２62，第 1 版，近代出 版, 東京 (1980).

2) 笹原二郎：獣医伝染病学, $131 \sim 133$, 第 1 版, 近 代出版, 東京 (1979).

3) 大森常良：家衛試水㺟会記事，9，16１7 (1960).

4) 石谷類造：家衛試水㺟会記事, 9，17 18 (1960).

5) 稲葉右二：家衛試水㺟会記事, 9, 19 20 (1960). 
$\mathrm{R}$ 群レンサ球菌による豚の化膿性䯣膜炎の発生
6) 農林省畜産局衛生課：日 獣 会 誌, 20，187～194
8) 大森常良：日獣会誌，20, 204 215 (1967). (1967).
7) 桑原志都夫 : 日獣会誌, 20, 197～203 (1967).
9) Omori, T.: Natl. Inst. Amin. Health Q. (Jpn.), 10, Suppl., 45 55 (1970).

\title{
$\mathrm{R}$ 群レンサ球菌による豚の化膿性䯣膜炎の発生
}

\section{岡本 至* 星野光男* 佐々木 理* 岩本仁司* 谷口佐富* 佐藤佳久*}

（昭和 58 年 7 月 15 日受理）

\author{
An Outbreak of Meningitis in Piglets with Group R Streptococci \\ ItARU OKAмото et al. (Chusei Livestock Hygiene Service \\ Center, Prefecture of Mie, Tsu-shi, Mie 514)
}

\begin{abstract}
SUMMARY
Streptococcal meningitis broke out among piglets 40100 days old on a farm in Mie Prefecture over a period from February to December, 1980. It was started with pyrexia over $40^{\circ} \mathrm{C}$, ataxia, and crouching like dogs. Affected piglets lay on the side, trembled, and paddled with all the four extremities. The main autopsy finding was thick opalescent turbidity of the meninges. Histological examination revealed purulent meningitis of the central nervous system. Streptococci were isolated from the brain, lung, liver, spleen, kidney, and joint. Judging from their biological characters and serological typing, they were probably identical with Moor's group $\mathrm{R}$ streptococci.
\end{abstract}

要約

三重県下の一養豚場で, 1980 年 2 月から 12 月の間に, レンサ球菌感染による豚の化膿性髄膜炎 が, 40 100 日齢の豚に発生した. 症状は $40^{\circ} \mathrm{C}$ 以上の発熱, 歩様失調, 起立困難, 犬座姿勢のほ か，けいれん，横臥中の四肢の前搔きなどの神経症状も見られた. 主な剖検所見は脳軟膜の白濁肥 厚が共通所見であった. 組織学的には脳拉よび脊髄の化膿性髄膜炎が特徵的であった. 細菌学的検 索で脳, 肝臓, 脾臓, 腎臓, 肺掞よび関節からレンサ球菌が分離され, 生物学的性状および血清学 的型別の結果, de Moor の Streptococcus R 群菌のそれと一致した.

豚の溶レン菌症と呼ばれている症患には敗血症, 多発 性関節炎, 心内膜炎, 膿瘍形成など多彩な病像を示し, とくに子豚での発生が多い，しかし，わが国での報告は きわめて少なく,とくに血清群の不明であることが多い。 近年レンサ球菌 $\mathrm{R}$ または $\mathrm{S}$ 群菌による, 子豚の髄膜炎が 多発していることが，イギリス ${ }^{8)}$, オランダ6), ついでド イッ2),オーストラリア3゙などで報告された。わが国では 1981 年, 東ら”がはじめて本病の発生について報告した が，筆者らも三重県下の一養豚場で，その発生を確認し たのでその概要を報告する.

\section{1. 材 料および方法}

1) 材 料

1980 年 4 月から 9 月までの間に, ふるえ, 犬座姿勢,

* 三重県中勢家畜保健衛生所 (三重県津市高茶屋小森 字大塚3841)
横臥などの臨床症状を呈して急死した 2 頭预よび鑑定殺 の 3 頭の子豚計 5 頭を供試した. 日齢は 40〜88 日齢で あった。

\section{2) 細 菌 学 的 検 查}

供試豚の主要藏器および脳，らち 2 頭については膝関 節および鼻汁について細菌培養を行った. $10 \%$ ヒジ血 液加ハートインフュージョン寒天平板培地を用い, $37^{\circ} \mathrm{C}$ 18 時間好気扣よび $10 \%$ 炭酸ガス条件下で嫌気培養した. 分離したレンサ球菌については, Cowan \& Steel ${ }^{10)} に$ 準 じて生物学的性状を調へ，同定には Bergey’s Manual (第 8 版 $)^{5)}$ も参考にした.

\section{3) 血清学 的 診 断}

抗原は Lancefield により作製した． $\mathrm{R}$ 群抗血清は家 畜衛生試験場から分与を受けた. 方法は寒天ゲル内沈降 反応によった.

\section{4)病理組織学的検査}

日獣会誌 $36 \quad 652 \sim 655$ （1983） 